\title{
Introduction
}

In April, 1964, a revolution took place in Brazil against the corruption, chaos, and creeping Communism of the regime of President João Goulart. Inflation was then gathering force with frightening speed. The high rate of economic growth that had characterized the Brazilian economy since World War II had given way to stagnation-in 1963 the per capita real income actually fell. The working class, which had managed to maintain its share of national income throughout the postwar inflation, suffered in that year a decline in that share. The balance-ofpayments problem was becoming acute. Both the educational lag and the agricultural lag, so marked in Brazil, were becoming worse. President Goulart had yet to fulfil any of his promises to the people (while preaching agrarian reform he was quietly changing his position from one of the biggest to much the biggest landowner in the country); and as one source of support after another dropped away from him, Brazilians began to fear that he would be compelled to resort to a "Fidelismo" style coup d'état in order to stay in power. The revolution took place; Castello Branco became the reluctant President, and Roberto de Oliveira Campos was appointed as his Minister of Planning.

One of the first steps of the new government was the preparation of the Action Program for 1964-1966, which was presented to Congress in mid-August. The document was some six hundred pages long. Over three hundred pages related to individual sectors-power, transport, agriculture, industry, education, housing, natural resources, and regional development-and the rest related to general economic policies. In preparation for the CIAP Country Review, in mid-October, an enlarged and refined version was produced, in two volumes. Volume I presented the general macroeconomics, Volume II the sectoral programs plus a review of economic events in 1963-1964 and an outline of actions already taken by the government.

The basic analytical framework was straightforward: inflation in Brazil had recently reached proportions which not only brought balance-of-payments disequilibrium, but which also endangered con- 
tinuous economic growth. Whatever may have been the arguments in the past regarding the effect of inflation on economic growth, by 1964 it was apparent that inflation must be checked as soon as possible, if healthy economic development were to be resumed. At the same time the government did not wish to retard growth unnecessarily nor to create mass unemployment during the transition period. Nor did it want to continue postponing, as the Goulart government had, badly needed reforms in the fields of taxation, education, land tenure, and public administration.

The government also wanted to check the process of "socialization by default"-that is, the gradual increase of the share of government in total investment resulting from inadequate investment incentives in the private sector. Accordingly, the government did not want to restrain the flow of credit to the private sector in a degree that would prevent private investment from keeping pace with the necessary minimum expansion of public investment. Certain minimum levels of investment (public and private) were needed to restore a satisfactory rate of increase in per capita income and to avoid increasing unemployment and underemployment. The state of the Brazilian economic organization is such that some investment in social overhead-especially transport, power, housing, and education-is necessary for continuing growth. Responsibility in this field has come to be assigned mainly to the public sector. When all efforts had been made to reduce current government expenses and transfer payments, a hard core of essential public outlays would remain, outlays which would be needed for economic growth itself.

The Action Program set forth five fundamental objectives of economic policy:

1. To accelerate the rate of economic growth, interrupted in 1962 1963;

2. To progressively curb the process of inflation during 1964-1965 so as to obtain reasonable equilibrium of prices at the beginning of 1966;

3. To alleviate regional and sectoral inequities and tensions created by social imbalances, through improvement of social conditions;

4. To assure, through investment policy, adequate conditions for productive employment to absorb the continuously expanding labor force;

5. To correct the tendency toward uncontrolled deficits in the balance of payments which menaces the continuity of economic development through strangulation of the capacity to import.

The revised version of the Action Program of the Brazilian govern- 
ment called for a progressive and programmed curbing of inflation. Monetary expansion in 1965 was to be so limited that the price increase during the year would be reduced to 25 percent. In 1966 the increase in means of payment would be held to 6 percent, equal to the projected increase in total output, so that price stability would be achieved.

The Action Program, unlike some of its predecessors, has been no "paper plan" to be discussed, shelved, and ignored. It has been the basis for action. The pace at which Congress passed the legislation called for in the Program rivalled that of the famous "hundred days" of the first Roosevelt Administration in the United States: two taxreform bills, a banking-reform bill, housing legislation, and-perhaps most significant of all after the performance of the Goulart Administration-a sweeping agrarian-reform bill. The law is designed primarily to provide family-size farms to the masses of landless farm laborers and to those with "splinter holdings" or fragmented farms. It provides for penal taxation on large unused or underused holdings, designed to force owners of such holdings to put them to effective use or sell them off in family-size units. There is also provision for outright expropriation. But the Act is no mere "soak-the-landlord" measure; its chief aim is to raise agricultural output, and the legislation also provides for agricultural credit, extension services, improved marketing facilities, soil surveys, cadastral surveys, and other agricultural benefits. The Act reflects both the government's insistence on "stabilization, development, and reform" and the high level of technical competence of the Administration, as do the other measures taken by the Branco government.

Nor is the Program a once-and-for-all affair. The Program is regarded as a rolling one, and work on the 1965-1967 plan had begun almost as soon as the ink was dry on the earlier Program. The Ministry of Planning is also at work on a long-run plan which will provide the basis for still another, more comprehensive implementation program for 19671970.

By the end of 1965 the government's economic program had already produced dramatic effects both at home and abroad. The price rise of 45 percent during the year was more than the 25 percent originally projected, but a clear indication that inflation was being brought under control; the rate of price increase was only about one third of what it was when the government took over. The balance-of-payments position was greatly improved. The shock-effect of the abrupt reversal of policy brought more slow-down in investment and more unemployment than the government would have liked, but by year's end expansion was 
under way again and employment was increasing. Foreign investors made a tangible vote of confidence by putting hundreds of millions of new dollars into expansion or initiation of Brazilian operations. The World Bank made a loan to Brazil for the first time in six years and the International Monetary Fund provided substantial stand-by credits for the first time in several years. Brazil has become one of the really largescale recipients of North American aid; and several European countries are also providing technical or capital assistance.

The chief architect of the Action Program was Minister of Planning Roberto Campos himself-a brilliant economist, an experienced diplomat, a development banker, and in addition a man of broad and deep culture, musician, poet, charming companion, and warm friend. As suggested in his acceptance speech when nominated as Man of the Year by the influential journal Visão, Roberto Campos had come a long way from his humble beginnings on the Mato Grosso frontier when he assumed the task of shaping the Brazilian economy. Campos likes to refer to himself as "a Brazilian hillbilly"; and indeed it is hard to guess what might have become of him if some Jesuit priests had not recognized the spark of genius in the small boy playing around their cloister, taken him in, and educated him as a priest. Before taking his final vows Campos recognized that his true calling lay elsewhere, but the warm humanity, deep concern for the fate of mankind, solid scholarship, and keen logic engendered by his early training have stayed with him ever since, as the essays presented below clearly show. Upon leaving the monastery he entered the Brazilian foreign service and went on to become, among other things, professor of economics at the University of Brazil, president of the National Bank for Economic Development, Brazilian representative to the General Agreement on Tariffs and Trade (GATT), ambassador to the United States, and now Minister of Planning.

Reading between the lines in some of the essays in this volume one can tell that Dr. Campos is well aware that he has chosen a lonely road. In a country accustomed to inflation for centuries, where every contract and transaction is geared to the expectation of a continuing rise in prices, only the far-sighted few could see the necessity for action as drastic as that set forth in the government's Program. The austere measures and sharp change in direction in the economy have been far from popular, and the ultimate benefits to the Brazilian people as a whole have not been immediately apparent. As the man mainly responsible for the government's economic policy Roberto Campos has borne 
the brunt of the attacks against it. He is also attacked for being excessively pro-American-his enemies refer to him slightingly as "Bob Fields," a literal translation of his name. Yet Campos is far from being uncritical of United States policy: the essays below include some sharp and penetrating criticisms of U.S. actions. Campos is not and never has been a blind adherent to an "American line." He does, however, see Brazil's future as lying with the West, and he knows that the term "American" as applied to the whole hemisphere has real content. Support for his Program is growing both at home and abroad. In some corners his name is being mentioned as a possible candidate for the Presidency.

Minister Campos' basic philosophy regarding planning and the role of the state in economic development emerges clearly from the essays published in this volume. For example, he makes a distinction between the "pragmatic" and the "romantic nationalists." Of the latter he says, "many of them, though they do not confess it, favor the dangerous surgery of revolution, while the pragmatic nationalist seeks to operate within the frame of democratic institutions and prefers reform to revolution." He adds,

I shall continue considering myself a pragmatic nationalist. I renounce the temptation of mobilizing resentment in order to gain the authority to plan development. I would rather strengthen the national entrepreneur than merely antagonize the foreigner. I would want the State not to do what it cannot do, in order to do what it should do. I prefer to love my own country rather than to hate the others.

Elsewhere he says of his countrymen, "We are not yet convinced of the very elementary truth that the State cannot give to the individual anything that it has not taken from the individual before."

I first met Roberto Campos in Geneva in 1960, when I had the privilege of working under his chairmanship in the International Labour Organization (ILO) Expert Group on Employment Objectives in Economic Development. During 1964 I had the still more inspiring opportunity of working in his Ministry on the completion and revision of the Action Program. I have twice had the pleasure of introducing Roberto Campos to audiences: once in Berlin to the meeting of Directors of Development Institutes, and once at The University of Texas when Dr. Campos delivered his Hackett Memorial Lecture. The lectures delivered on both these occasions are reproduced below. It gives me still greater pleasure now to introduce Dr. Campos to the wider audience 
of readers of this volume. Roberto Campos is clearly one of Latin America's most distinguished economists and statesmen; his views on Latin American economic development, and on United States-Latin American relations, have an interest far beyond the limits of the economics profession.

\section{Benjamin Higgins}

Ashbel Smith Professor of Economics The University of Texas 